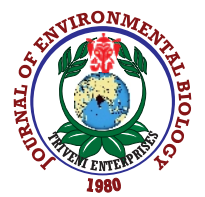

\title{
Growth of tropical cladocerans Ceriodaphnia cornuta G.O. Sars, 1885 and Moina micrura Kurz, 1875 fed with different diets
}

\author{
N.L. Latib ${ }^{1}$, F.Md. Yusoff ${ }^{1,2,3 *}$, N. Nagao ${ }^{2}$ and H. Nizar ${ }^{1}$ \\ 'Department of Aquaculture, Faculty of Agriculture, Universiti Putra Malaysia, 43400 Serdang, Selangor, Malaysia \\ ${ }^{2}$ International Institute of Aquaculture and Aquatic Sciences, Universiti Putra Malaysia, 71050 Port Dickson, Negeri Sembilan, Malaysia \\ ${ }^{3}$ Laboratory of Marine Biotechnology, Institute of Biosciences, Universiti Putra Malaysia, 43400 Serdang, Selangor, Malaysia \\ *Corresponding Author Email : fatimamy@upm.edu.my
}

\begin{abstract}
Aim: To examine the effects of different feed types (live microalgae diets and processed diets) on the growth of tropical cladocerans, Ceriodaphnia cornuta G.O. Sars, 1885 and Moina micrura Kurz, 1875.

Methodology: Zooplankton samples were collected from a small pond in the Universiti Putra Malaysia (UPM). Live zooplankton samples were brought to the laboratory for identification, isolation, and mass culture. Experiments were accomplished by providing ad libitum feeding to zooplankton (approximately $1.0 \times 10^{6}$ cells mL density for live algae diets and $0.01 \mathrm{mg} \mathrm{ml}^{-1}$ for processed diets) with three replicates for each diet. The two processed diets were the baker's yeast and Spirulina powder, and two live-algal diets were Chlorella sorokiniana Shihira and Krauss, 1965 and Chlorella vulgaris M. Beyerinck [Beijerinck], 1890. Zooplankton population density was counted every third day under a dissecting microscope by sampling $25 \mathrm{ml}$ of wellmixed culture. The experiments were terminated when the population stabilized or began to decline.
\end{abstract}

Results: Cultures of Ceriodaphnia cornuta and Moina micrura showed the highest $(p<0.05)$ mean population density, specific growth rate and body size when fed with live algae diets compared to the processed diets. Ceriodaphnia cornuta produced the highest population density $\left(1670.0\right.$ individual $\left.I^{-1}\right)$, specific growth rate $(\mu=0.19)$, and body size $(393.0 \mu \mathrm{m})$ in Chlorella sorokiniana diet. While M. micrura generated the highest population density (3993.67 individual $\left.I^{-1}\right)$, specific growth rate $(\mu=0.40)$, and body size $(783.97$ $\mu \mathrm{m})$ in the culture fed with Chlorella vulgaris. The lowest population density for $C$. cornuta was Spirulina powder culture and baker's yeast culture for M. micrura.

Interpretation: The results of the present study illustrated that both algae diets produced significantly higher $(p<0.05)$ population growth rate and body size than non-algal diets. Live algal diets are better food items for the growth of cladocerans, Ceriodaphnia cornuta and Moina micrura as compared to processed diets.

Key words: Ceriodaphnia cornuta, Moina micrura, Population density, Tropical cladocerans

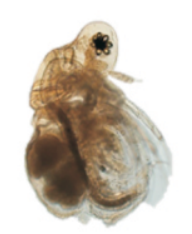

Moina micrura



Fed different Chlorella sorokiniana types of diets

Baker's yeast

Ceriodaphnia cornuta

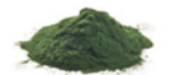

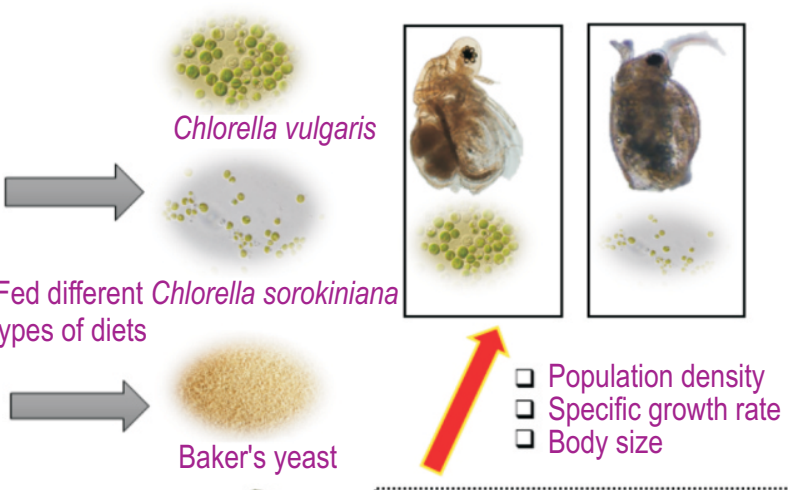

Spirulina powder
Live microalgae formed significantly better feed than yeast and spirulina powder for both cladocerans

How to cite : Latib, N.L., F.Md. Yusoff, N. Nagao and H. Nizar: Growth of tropical cladocerans Ceriodaphnia cornuta G.O. Sars, 1885 and Moina micrura Kurz, 1875 fed with different diets. J. Environ. Biol., 41, 1224-1229 (2020). 


\section{Introduction}

Zooplankton forms one of the most important links in aquatic food chain and supports fishery resources in many different inland and marine ecosystems. Zooplankton commonly depends on algae, microbes, and particulate organic matter as its food sources in aquatic ecosystems (Alva-Martinez et al., 2007; Long et al., 2019; Tellioglu, 2013). In aquaculture industry, both phytoplankton and zooplankton function as live foods for commercially important fish and other aquatic organisms because they are easily digestible protein rich diets (Das et al., 2012). The ability of live food species to move in water column make them regularly available to fish and shellfish larvae and projected to encourage larval feeding response (David, 2003). Most shellfish and fish larvae require phytoplankton and small zooplankton as their first food to achieve fast growth and high survival (Evjemo et al., 2003). In fact, shellfish and fish larvae do not respond to artificial supplemented feed as well as they do to live feed.

Cladocerans are one of the important zooplankton groups, beside rotifers and copepods. Many species of cladocerans are filter-feeders and rely heavily on phytoplankton for their main feeding regime (Khatoon et al., 2012), due to microalgae high nutritional content and suitable size (Choi et al., 2014; Muñoz-Mejía and Martínez-Jerónimo, 2007). Ceriodaphnia cornuta and Moina micrura are freshwater zooplankton, commonly found in tropical lakes and ponds. Moina micrura is an important live food in aquaculture since it is rich in nutritional contents and capable of improving larval growth and development of many cultured species (Azuraidi et al., 2013). In general, cladocerans are ideal live foods as they have digestive enzymes, high nutritional quality, and suitable body sizes (0.2-6 $\mathrm{mm}$ ) for many species of fish and invertebrate larvae (Dodson and Frey, 1991; Kumar et al., 2005; Nandini and Sarma, 2003; Srivastava et al., 2006).

Most cladoceran species are capable of consuming unicellular algae with size ranging between $2 \mu \mathrm{m}$ to $25 \mu \mathrm{m}$ (Das et al., 2012; Flores-Burgos et al., 2003). However, large colonial, filamentous and spinous algal species are unfavorable for them (Fulton, 2006; Guo and Xie, 2006 and Lurling, 2003). Cladoceran species mainly depend on few groups of algae such as chlorophytes (Gołdyn and Kowalczewska-Madura, 2012; Repka, 1997) cryptophyes (Li et al., 1996), and autotrophic flagellates (Ahlgren et al., 1990) for enhancement of their growth and reproduction. On the other hand, blue-green algae can reduce the growth of cladocerans (Urrutia-Cordero et al., 2015) mainly due to cyanotoxin (Adibah et al., 2020). Some studies have reported that cell morphology, biochemical composition, and nutritional content show difference in growth response of zooplankton towards microalgal species (Alva-Martinez et al., 2004; Bec et al., 2003; Elser et al., 2001; Tõnno et al., 2016; Urabe et al., 2003).
The quality and quantity of phytoplankton consumed are key factors that govern the growth of cladoceran populations (Choi et al., 2014). This study evaluated the effects of using microalgae diets to improve the population growth rates of Ceriodaphnia cornuta and Moina micrura, which can be further used to enhance the live-food production for the aquaculture industry.

\section{Materials and Methods}

Isolation of species : Ceriodaphnia cornuta and Moina micrura samples were collected from pond 5 in Bukit Ekspo, Universiti Putra Malaysia, by passing water samples through a $60-\mu \mathrm{m}$ sieve several times. Live Ceriodaphnia cornuta and Moina micrura samples were kept in one litre plastic bottles and carried to the laboratory for isolation and identification of species. The samples were then examined under dissecting microscope to confirm the species and then samples were cultured in one litre flasks containing filtered pond water using $25 \mu \mathrm{m}$ net. One parthenogenetic female with eggs was transferred to a $50 \mathrm{ml}$ beaker to ensure a pure mono-species stock. Many beakers, each containing one female were prepared as stock cultures. For stock culture, samples were maintained and fed with green water culture until the eggs were hatched and the neonates grew to adults. Each culture was examined daily during the stock maintenance. All dead individuals were noted and removed from the beaker. All wastes were also removed, and water in the beaker was changed daily up to $30 \%$. Zooplankton from the third generation were selected for the study to ensure the parental effects and phenotypic tractability maintained from the stock culture according to Lynch and Ennis (1983).

Culture of algae as feed : Chlorella vulgaris and Chlorella sorokiniana were used in this experiment. Pure stock cultures of two algae were grown using BG-11 medium (Rippka et al., 1979). The cultures were kept and maintained in General Research Laboratory, Department of Aquaculture, Faculty of Agriculture, UPM under the control temperature of $25 \pm 2^{\circ} \mathrm{C}$ and light and dark cycle of $12 \mathrm{hr}$ light: $12 \mathrm{hr}$ dark with mild continuous aeration. The algae concentrations were determined using an improved Neubauer hemocytometer $\left(0.25 \mathrm{~mm}^{2} \times 0.1 \mathrm{~mm}\right)$ under a dissecting microscope after samples were fixed with Lugol's solution.

Experimental design : Experiments were performed to test the effects of different food types on population growth rate and density of Ceriodaphnia cornuta and Moina micrura using two live microalgae diets: Chlorella vulgaris and Chlorella sorokiniana, and two processed diets: baker's yeast, Saccharomyces cerevisiae and Spirulina powder, with three replicates for each diet. Ceriodaphnia cornuta and Moina micrura were fed with approximately $1.0 \times 10^{6} \mathrm{cells} \mathrm{ml}^{-1}$ density for live algal diets and $0.01 \mathrm{mg} \mathrm{ml}^{-1}$ for processed diets every day. Water quality was regularly checked to avoid overfeeding, which was indicated by a 
cloudy medium or left-over food precipitation (Matias-Peralta et al., 2011). Two hundred females were transferred to one litre conical flask containing filter-sterilized freshwater pond water $(\mathrm{pH}$ $6.9-7.5$, temperature $25.0^{\circ} \mathrm{C}$ and dissolved oxygen $6.6 \mathrm{mg} \mathrm{l}^{-1}$ ) for initial stocking density. Temperature, salinity and photoperiod were kept same as in the stock culture. The culture medium was changed $100 \%$ every third day. The flasks were manually shaken every day to maintain homogenous condition inside the flasks. When the population stabilized or began to decline the experiments were terminated. Every third day, population density for both species were determined by removing $25 \mathrm{ml}$ of wellmixed culture and counted under a dissecting microscope (Azuraidi et al., 2013). Population growth rate was calculated by the following formula:

$$
\text { Population growth rate, } \mu=\frac{\left(\ln ^{x_{1}}-\ln ^{x_{2}}\right)}{T}
$$

Where, $X_{1}$ is the population density at the start of selected time interval; $X_{2}$ is the population density at the final of selected time interval and $T$ is the time in days

Statistical analysis : All the data recorded were analyzed by one-way analysis of variance (ANOVA) with the Statistical Package for Social Science, SPSS (version 20). Duncan's Multiple Range Test was used to test the mean differences. All data were tested for homogeneity of variance earlier to satisfy the condition of normal distribution.

\section{Results and Discussion}

In this study, the population densities and growth rates of C.cornuta and $M$. moina fed with algal diets were significantly higher $(p<0.05)$ as compared to those fed with baker's yeast and Spirulina powder (Figs. 1, 2, 3 and 4). Ceriodaphnia cornuta fed with Chlorella sorokiniana showed the highest $(p<0.05)$ mean

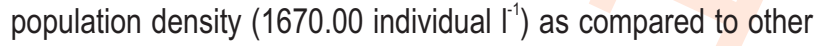
diets (Fig.1). However, the population density fed with C. sorokiniana started declining on day 18 due to a highly crowded condition (Fig. 1). Meanwhile, there were no significant difference $(p>0.05)$ between cladocerans fed with Chlorella vulgaris, baker's yeast and Spirulina powder as C.cornuta showed poor growth in all these cultures. Spirulina powder failed to produce sustainable population density because all the individuals started to decline and die during first three days of culture (Fig. 1).

Only C. cornuta fed with C. sorokiniana showed significantly higher $(p<0.05)$ specific growth rate when compared with other diets. The highest specific growth rate was recorded in the cultures fed with $C$. sorokiniana $(0.19)$ followed by cultures fed with C. vulgaris and baker's yeast (Fig. 2). Negative growth rate was recorded for Spirulina powder because of the inability of C.cornuta to survive when fed with Spirulina powder (Fig.1).

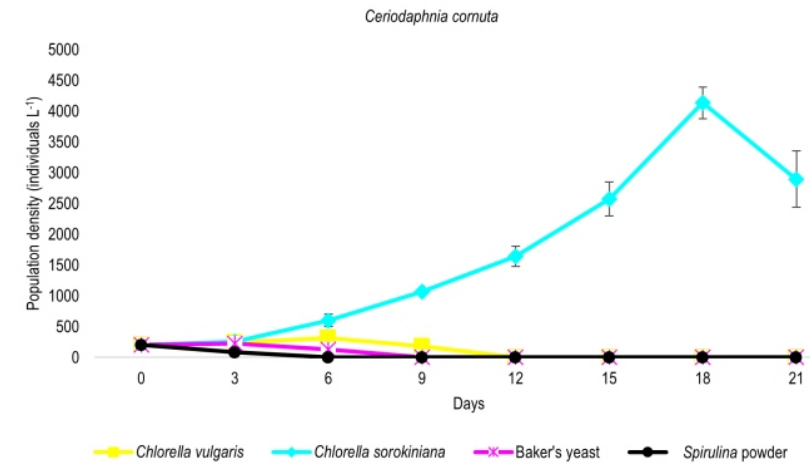

Fig. 1 : Mean population densities of Ceriodaphnia cornuta fed with different diets $(n=3)$. All Ceriodaphnia cornuta fed with Spirulina powder died after three days. Vertical bars indicate standard error of means.

Ceriodaphnia cornuta

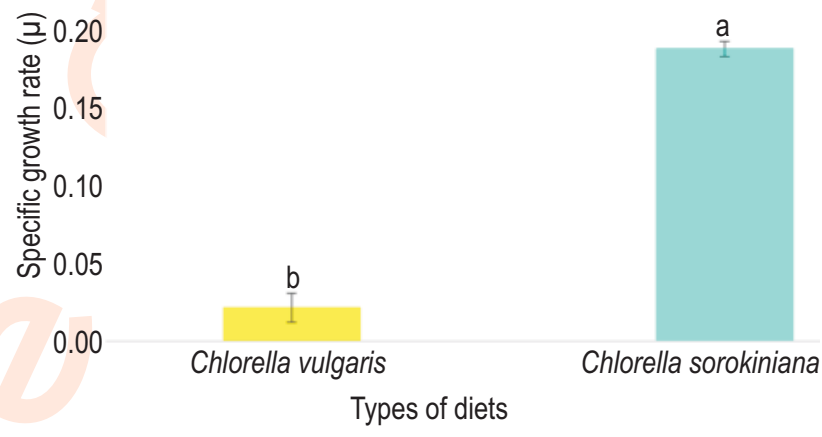

Fig. 2 : Mean specific growth rates $(\mu)$ of Ceriodaphnia cornuta fed with different diets. Bars with different letters indicate that the means are significantly different at $p<0.05$.

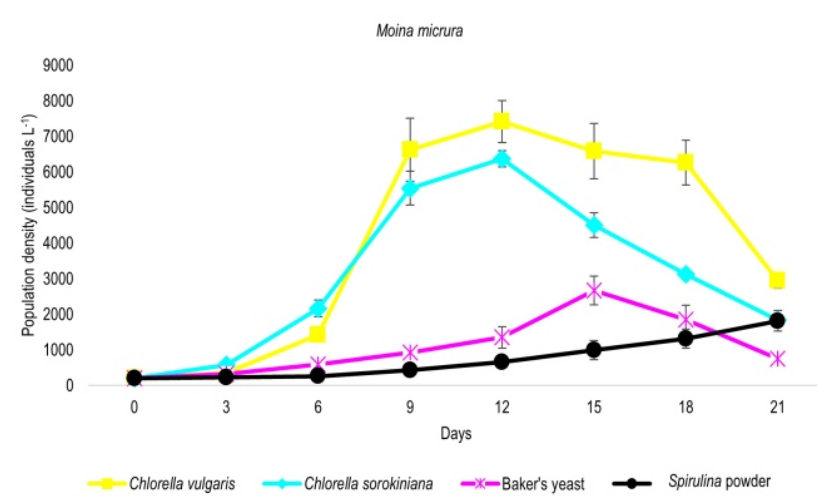

Fig. 3 : Mean population densities of Moina micrura fed with different types of diet.

Different from C. cornuta, M. micrura showed significantly higher densities and growth rates when fed with both Chlorella species as compared to baker's yeast and Spirulina power (Fig. 3 and 4), probably due to latter's bigger size that allowed them to filter larger food particles. Moina micrura cultured with Spirulina 
powder showed slow growth with a long lag phase and delayed peak density as compared to C. cornuta, which did not show any significant growth (Fig. 1 and 3). Even though Spirulina powder had the longest culture period up to 30 days for M. micrura, however, the population density was significantly lower $(p<0.05)$ as compared to live microalgae diets. The other three diets showed almost similar pattern of population growth curve when they reached maximum density on $12^{\text {th }}$ day for those fed with $C$. vulgaris and $C$. sorokiniana, and $15^{\text {th }}$ day for baker's yeast.

In general, the mean body size for $C$. cornuta was less than $400 \mu \mathrm{m}$. Individuals of $C$. cornuta fed with $C$. sorokiniana showed the biggest $(p<0.05)$ mean size $(392.99 \mu \mathrm{m})$, followed by those fed with $C$. vulgaris and bakers yeast (Fig 5). No significant difference $(p>0.05)$ was detected between those fed with $C$. vulgaris and baker's yeast. Ceriodaphnia cornuta fed with Spirulina powder died after 9 th day of culture.

The mean size of $M$. micrura fed with $C$. vulgaris were significantly different $(p<0.05)$ as compared to baker's yeast but had no significant difference ( $p>0.05$ ) with $C$. sorokiniana and Spirulina powder. The biggest individuals of $M$. micrura were found in culture with $C$. vulgaris $(783.97 \mu \mathrm{m})$ followed by $C$. sorokiniana and Spirulina powder (Fig. 6). The smallest individual M. micrura was observed in the culture of baker's yeast.

According to Ger et al. (2016), cyanobacteria is regarded as a poor quality food mainly due their toxicity and morphology. For example, Spirulina is a filamentous, long, and appears as blue-green spiral threads. Previous studies have shown that most cladoceran species do not easily ingest large colonial, filamentous and spinous microalgal species (Alva-Martínez et al., 2007; Hartmann and Kunkel, 1991; Lurling, 2003). Most zooplankton species that feed on cyanobacteria alone tend to grow slower, delayed reproduction, and generally increased mortality (Munirasu et al., 2016; Tillmanns et al., 2008; Webster and Peters, 1978). The low population growth observed in cultures with Spirulina powder diet might have been due to the relatively large size of algal cells and its filamentous composition that makes them less acceptable for both cladocerans.

Gulati and DeMott (1997) reported that zooplankton fed with only baker's yeast proved to be a poor dietary source. However, mixed baker's yeast and other food sources such as microalgae could increase the survival level of zooplankton (LaRocca et al., 1994; Gomez et al., 2012; Khatun et al., 2014). Zooplankton species including $C$. dubia that were given diet containing baker's yeast reached low growth density (PenaAguado et al., 2005). In addition, population growth of Apocyclops dengizicus fed on baker's yeast also resulted in poor population growth density (Farhadian et al., 2008).

Cladocerans are able to eat unicellular algae of dimension $2 \mu \mathrm{m}$ to $25 \mu \mathrm{m}$ (Flores-Burgos et al., 2003). Previous

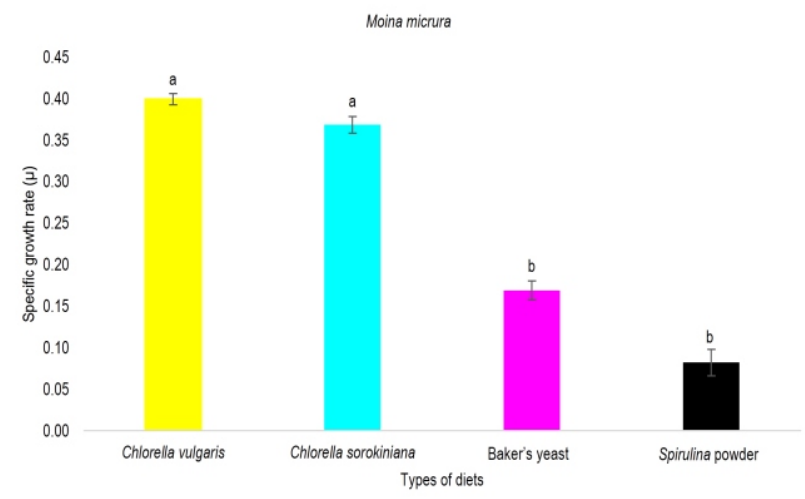

Fig. 4 : Mean specific growth rates $(\mu)$ of Moina micrura fed with different types of diets. Bars with different letters indicate that means are significantly different at $p<0.05$.

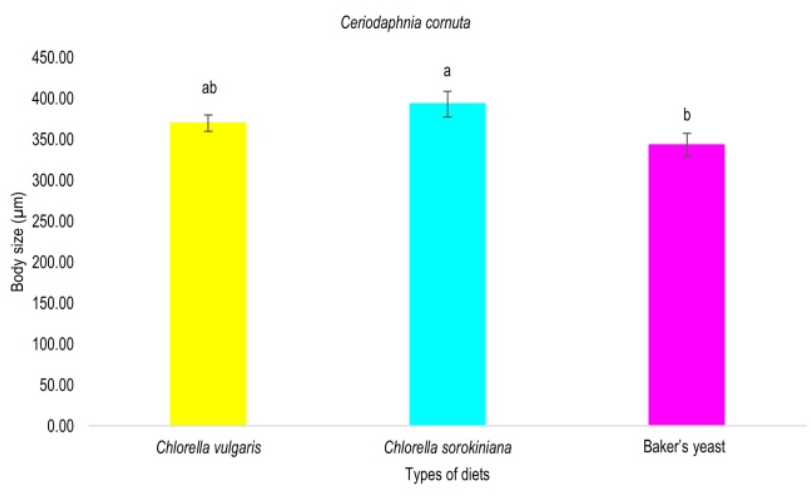

Fig. 5 : Mean body size of individual of Ceriodaphnia cornuta fed with different types of diets. Different letters indicate significant difference $(p<$ 0.05). All C. cornuta fed with Spirulina powder died on 3rd day of culture.

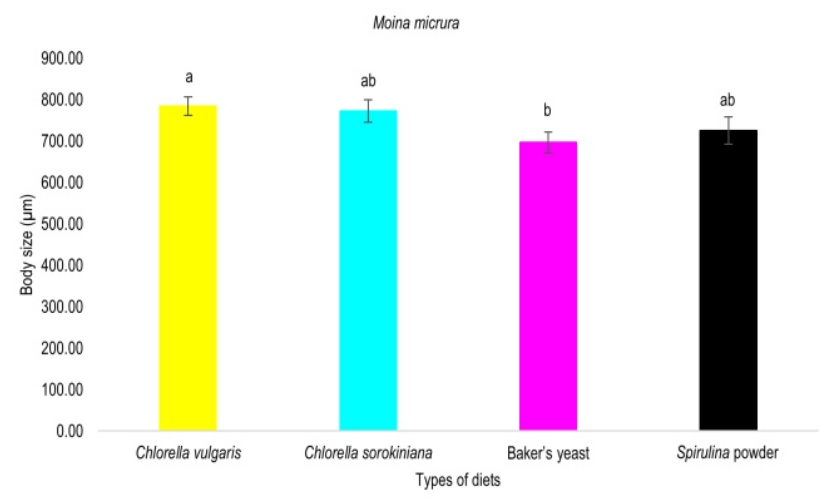

Fig. 6 : Mean body size of Moina micrura fed with different types of diets. Different letters indicate significant difference $(p<0.05)$. Vertical bars are standard errors of the means.

studies suggested that maximum food particles that could be ingested depend on the body size (Bogdan and Gilbert, 1984; Burns, 1968). Vijverberg (1989) reported that green algae were good quality food sources for zooplankton. This evidence was 
supported by Alva-Martinez et al. (2007) when C. dubia had a longer culture period when fed with $C$. vulgaris than cyanobacterial species. Moina macrocopa generally has higher growth rate when fed with $C$. vulgaris than many species of cladocerans, including C. dubia (Mangas-Ramırez et al., 2002; Pena-Aguado et al., 2005).

In this study, C. cornuta was able to grow well on $C$. sorokiniana but showed poor growth on $C$. vulgaris, probably due to the fact that $C$ sorokiniana was smaller (mean size $<3 \mu \mathrm{m}$ ) than C. vulgaris (mean size $>5 \mu \mathrm{m}$ ). Umi et al. (2020) reported that $C$. cornuta was dominant in eutrophic lake as they can feed on small bacterial cells from the decomposed algal mass. Thus, lower growth rates of small $C$. cornuta when fed with $C$. vulgaris could be due to larger cell size of $C$. vulgaris as compared to $C$. sorokiniana. In addition, the body size of $C$. cornuta was approximately two times smaller than M. micrura (Fig. 5, 6). In this study, the body size of $C$.cornuta was less than $400 \mu \mathrm{m}$, indicating that they have small body size compared to previous reports (Freitas et al., 2007; Srivastava et al., 2006). Muñoz-Mejía and Martínez-Jerónimo (2007) reported that cladocerans are able to eat and adapt to any food item within the size range of their filtering capacity. When they have a small body size, distances between the setulae on moving appendages, which act as filters the feed might also small in size. This would restrict their diets and cause difficulty for small-sized cladocerans to eat big food particles size (He et al., 2001).

In conclusion, live microalgae diets such as Chlorella spp showed better effects on the growth of cladoceran zooplankton populations ( $C$. cornuta and M. micrura) compared to bakers' yeast and Spirulina powder, which could be due to better nutritional quality of the fresh live foods than processed ones. This study showed the correct matching between the zooplankton body size and the size of food particles is important in determining the effectiveness of food type on zooplankton growth rate.

\section{Acknowledgments}

This study was funded by the Ministry of Higher Education under the SATREPS-COSMOS (Project No. JPMJSA 1509) collaborative Malaysia-Japan project. Our thanks and appreciation to the laboratory staff at the Department of Aquaculture for their technical assistance.

\section{References}

Adibah, S., F.M. Yusoff, I.S. Ismail and T. Toda: Reduced reproductive capacity in Moina micrura Kurz, 1875 exposed to toxic Microcystis spp. Asian Fisheries Science. In Press. https://doi.org/10.33997/ j.afs.2020.33.1.005 (2020)

Ahlgren, G., L. Lundstedt, M. Brett and C. Forsberg: Lipid composition and food quality of some freshwater phytoplankton for cladoceran zooplankters. J. Plank. Res., 12, 809-818 (1990).

Alva-Martinez, A.F., S.S.S. Sarma and S. Nandini: Effect of mixed diets (cyanobacteria and green algae) on the population growth of the cladocerans Ceriodaphnia dubia and Moina macrocopa. Aquat. Ecol., 41, 579-585. (2007).

Azuraidi, O.M., F.M. Yusoff, M.N. Shamsudin, R.A. Raha, V.R. Alekseev and H.M. Matias-Peralta: Effect of food density on male appearance and ephippia production in a tropical cladoceran, Moina micrura Kurz, 1874. Aquaculture, 412-413, 131-135 (2013).

Bec, A., C. Desvilettes, A. Vera, D. Fontvieille and G. Bourdier: Nutritional value of different food sources for the benthic Daphnidae Simocephalus vetulus: Role of fatty acids. Hydrobiologia, 156, 145-163 (2003).

Bogdan, K.G. and J.J. Gilbert: Body size and food size in freshwater zooplankton. Proc. Natl. Acad. Sci. U.S.A., 81, 6427-6431 (1984).

Burns, C.W.: The relationship between body size of filter feeding Cladocera and the maximum size of particle ingested. Limnol. Oceanogr., 13, 675-678(1968).

Choi, J.Y., S.K. Kim, K.H. Chang, M.C. Kim, G.H. La, G.J. Joo and K.S. Jeong: Population growth of the Cladoceran, Daphnia magna: A quantitative analysis of the effects of different algal food. Plos ONE, 9, e95591 (2014).

Das, P., S.C. Mandal, S.K. Bhagabati, M.S. Akhtar and S.K. Singh: Important live food organisms and their role in aquaculture. In: Frontiers in Aquaculture (Ed.: M. Sukham). Narendra Publishing House, pp. 69-86 (2012).

David, A.B.: Status of marine aquaculture in relation to live prey: past, present and future. In: Live Feeds in Marine Aquaculture (Eds.: G.S. Josianne and A.M Lesley). Blackwell Publishing, U.K., pp. 116 (2003).

Dodson, S.I. and D.G. Frey: Ecology of cladocerans. In: Ecology and Classification of North American Freshwater Invertebrates (Eds. J.H. Thorp and A.P. Covich). Academic Press, NY., pp. 730-743 (1991).

Elser, J.J., K. Hayakawa and J. Urabe: Nutrient limitation reduces food quality for zooplankton: Daphnia response to seston phosphorus enrichment. Ecol., 82, 898-903 (2001).

Evjemo, J.O., K.I. Reitan and Y. Olsen: Copepods as live food organisms in the larval rearing of halibut larvae (Hippoglossus hippoglossus L.) with special emphasis on the nutritional value. Aquaculture, 227, 191-210 (2003).

Farhadian, O., F.M. Yusoff and A. Arshad: Population growth and production of Apocyclops dengizicus (Copepoda: Cyclopoida) fed on different diets. J. World Aquacult. Soc., 39, 384-396 (2008).

Flores-Burgos, J., S.S.S. Sarma and S. Nandini: Population growth of zooplankton (rotifers and cladocerans) fed Chlorella vulgaris and Scenedesmus acutus in different proportions. Acta Hydrochim. Hydrobiol., 31, 240-248 (2003).

Freitas, G.T.P., M.C. Crispim and M.I.M. Hernandéz: Changes in lifehistory parameters of cladoceran Ceriodaphnia cornuta (Sars, 1886 ) in the presence of Chaoborus larvae. Acta Limnol. Bras., 19, 295-303 (2007).

Fulton, R.S.: Grazing on filamentous algae by herbivorous zooplankton. Freshwat. Biol., 20, 263-271 (2006).

Ger, K.A., P.U. Cordero, P.C. Frost, L.A. Hansson, O. Sarnelle, A.E. Wilson and M. Lürling: The interaction between cyanobacteria and zooplankton in a more eutrophic world. Harmful Algae, 54, 128144 (2016).

Goldyn, R. and K. Kowalczewska-Madura: Interactions between phytoplankton and zooplankton in the hypertrophic Swarzędzkie Lake in western Poland. J. Plank. Res., 30, 33-42 (2008). 
Gomez, M., I. Martınez, I. Mayo, J.M. Morales, A. Santana and T.T. Packard: Testing zooplankton secondary production models against Daphnia magna growth. ICES J. Mar. Sci., 69, 421-428 (2012).

Gulati, R. and W. Demott: The role of food quality for zooplankton: remarks on the state of the art, perspectives and priorities. Freshw. Biol., 38, 753-768 (1997).

Guo, N. and P. Xie: Development of tolerance against toxic Microcystis aeruginosa in three cladocerans and the ecological implications. Environ. Pollut., 143, 513-518 (2006).

Hartmann, H.J. and D.D. Kunkel: Mechanisms of food selection in Daphnia. Hydrobiologia, 225, 129-154 (1991).

He, Z.H., J.G. Qin., Y. Wang., H. Jiang and Z. Wen: Biology of Moina mongolica (Moinidae, Cladocera) and perspective as live food for marine fish larvae: Review. Hydrobiologia, 457, 25-37 (2001).

Khatoon, H., S. Banerjee, F.M. Yusoff and M. Shariff: Use of microalgalenriched Diaphanosoma celebensis Stingelin, 1900 for rearing Litopenaeus vannamei (Boone, 1931) postlarvae. Aquac. Nutr., 19, 163-171 (2012).

Khatun, B., R. Rahman and M.S. Rahman: Evaluation of yeast Saccharomyces cerevisiae and algae Chlorella vulgaris as diet for rotifer Brachionus calyciflorus. The Agriculturists, 12, 1-9 (2014).

Kumar, S., A. Srivastava and R. Chakrabarti: Study of digestive proteinases and proteinase inhibitors of Daphnia carinata. Aquaculture, 243, 367-372(2005).

LaRocca, C.A., D.E. Francisco and F.A. DiGiano: Effects of diet on survival, reproduction, and sensitivity of Ceriodaphnia dubia. WaterEnviron. Res., 66, 905-911 (1994).

Li, A., D.K. Stoecker, D.W. Coats and E.J. Adam: Ingestion of fluorescently labeled and phycoerythrin-containing prey by mixotrophic dinoflagellates. Aquat. Microb. Ecol., 10, 139-147 (1996).

Long, S., P.B. Hamilton, H.J. Dumont, L. Rong, Z. Wu, C. Chen, J. Tang, J. Fan, C. Li and T. Zhang: Effect of algal and bacterial diet on metal bioaccumulation in zooplankton from the Pearl River, South China. Sci. Total Environ., 675, 151-164 (2019).

Lurling, M.: Phenotypic plasticity in the green algae Desmodesmus and Scenedesmus with special reference to the induction of defensive morphology. Ann. Limnol. Int. J. Lim., 39, 85-101 (2003).

Lynch, M. and R. Ennis: Resource availability, maternal effects, and longevity. Exp Gerontol., 18, 147-165 (1983).

Mangas-Ramirez, E., S.S.S. Sarma and S. Nandini: Combined effects of algal (Chlorella vulgaris) density and ammonia concentration on the population dynamics of Ceriodaphnia dubia and Moina macrocopa (Cladocera). Ecotox. Environ. Safe., 51, 216-222 (2002)

Matias-Peralta, H.M., F.M. Yusoff, M. Shariff and M. Suhaila: Small-scale continuous production of a tropical marine copepod, Nitocra affinis californica Lang and its potential as live food for aquaculture. Afr. J.
Agric. Res., 6, 1611-1620 (2011).

Munirasu, S., V. Uthayakumar, P. Arunkumar and V. Ramasubramanian: The effect of different feeds such as Chlorella vulgaris, Azolla pinnata and yeast on the population growth of Daphnia magna commonly found in freshwater systems. Int. J. Fish. Aquat. Stud., 4,5-10 (2016).

Muñoz-Mejía, G. and F. Martínez-Jerónimo: Impact of algae and their concentrations on the reproduction and longevity of cladocerans. Ann. Limnol. Int. J. Lim., 43, 167-177 (2007).

Nandini, S. and S.S.S. Sarma: Population growth of some genera of cladocerans in relation to algal food (Chlorella vulgaris) levels. Hydrobiologia, 491, 211-219 (2003).

Pena-Aguado, F., S. Nandini and S.S.S. Sarma: Differences in population growth of rotifers and cladocerans raised on algal diets supplemented with yeast. Limnologica, 35, 298-303 (2005).

Repka, S.: Effects of food type on the life history of Daphnia clones from lakes differing in trophic state. II. Daphnia cucullata feeding on mixed diets. Freshw. Biol., 38, 685-692 (1997).

Rippka, R., J. Deruelles, J.B. Waterbury, M. Herdman and R.Y. Stainer: Generic assignment, strain histories and properties of pure cultures of cyanobacteria. J. Gen. Microbiol., 111, 1 - 61 (1979).

Srivastava, A., R.M. Rathore and R. Chakrabarti: Effects of four different doses of organic manures in the production of Ceriodaphnia cornuta. Bioresour. Technol., 97, 1036-1040 (2006).

Tellioglu, A.: Food selectivity of Ceriodaphnia quadrangula (O.F. Müller, 1785) (Cladocera) and its impact on competition outcome between two freshwater green algae. Crustaceana, 86, 1550-1563 (2013).

Tillmanns, A.R., A.E. Wilson, F.R. Pick and O. Sarnelle: Meta-analysis of cyanobacterial effects on zooplankton population growth rate: Species-specific responses. Fundam. Appl. Limnol., 171, 285-295 (2008).

Tõnno I., H. Agasild, T. Kõiv, R. Freiberg, P. Nõges and T. Nõges: Algal diet of small-bodied crustacean zooplankton in a cyanobacteriadominated eutrophic lake. PLoS ONE, 11, e0154526 (2016).

Umi W.A.D., F.M. Yusoff, A.Z. Aris, Z Sharip and A.Y. Sinev: Planktonic mirocrustacean community structure varies with trophic status and environmental variables in tropical shallow lakes in Malaysia. Diversity, 12, 322 (2020). https://doi.org/ 10.3390/d12090322

Urabe, J., J. Togari and J.J. Elser: Stoichiometric impacts of increased carbon dioxide on a planktonic herbivore. Glob. Chang. Biol., 9 , 818-825(2003).

Urrutia-Cordero, P., M.K. Ekvall and L.A. Hansson: Response of cyanobacteria to herbivorous zooplankton across predator regimes: who mows the bloom? Freshw. Biol., 60, 960-972 (2015).

Vijverberg, J.: Culture techniques for studies on the growth, development and reproduction of copepods and Cladocerans under laboratory and in situ conditions: Areview. Freshw. Biol., 21, 317-373 (1989).

Webster, K. and R. Peters: Some size-dependent inhibitions of larger Cladoceran filterers in filamentous suspensions. Limno. Oceanogr., 23, 1238-1245 (1978). 